e slumps in a corner of the charity clinic on a Calcutta street. To enter, he has climbed over an open drain, through which swirls an ocean of detritus. To stay, you must hold your nose.

His body is burning, his eyes are glazed. When he breathes, the tendons in his gaunt neck complain. Around him there is noisy human traffic but he doesn't mind: he is actually sliding into unconsciousness before our eyes. His mother tells us that everyone in their household has tuberculosis, he's just the sickest. She tried taking him to the public hospital but the queues are too long, the staff brusque, and her meagre earnings inadequate to cover the basic fee. You must help him, she pleads. He is my son. With him lies our destiny.

Watching him I consider his needs. Prompt treatment and contact tracing. Also compassion and luck. The best we can do is bandage open wounds, prescribe whatever scant, donated antibiotics, and ration paracetamol. Despondently, I empty my pockets before his mother. This will help. Take him to the hospital now.

She accepts the money gratefully. She is mad with helplessness, her mother's instinct sensing doom. I am sorry, I mouth. I wish there was something else. It's the curse of poverty, she says, our lot in life. Silently, she caresses him. He is 19. As she half carries, half pushes him, I realise I don't even know his name.

$$
* * *
$$

Her doctor and the ambulance have already alerted us to the patient in the emergency room in Melbourne. Three senior doctors stand ready to receive her. One puts in a line, another personally pushes the antibiotics, the third attends to the rest. She looks moribund on arrival but within hours, we breathe a sigh of relief. Nevertheless, she is taken to the ICU — "just to be sure", we console her mother. Her doctors are feted - she has lived to tell the tale of surviving meningococcal disease.

$$
* * *
$$

The world of medicine thrives on contrasts. An Australian infant can expect to live up to 90 years. The global life expectancy is a mere 68 , an age which we here classify as "relatively young". That Indian youth is but one of nearly 1.5 million ill fated sufferers that year. If he'd survived tuberculosis, chances are he would succumb to one of the other top 10 causes of developing-world mortality. The young lady who luckily survived meningitis is far more likely to die of one of the "lifestyle diseases" that account for nine out of the top 10 killers in the rich world. While a patient in Melbourne demands (and receives) an exorbitantly priced treatment of questionable value, a patient in Mozambique dies with a face unrecognisably mauled by the same cancer. If you fall ill in London, you can reliably turn to a public hospital. Yet, in Libya, the cupboards lie bare. Fully 50 per cent of global public

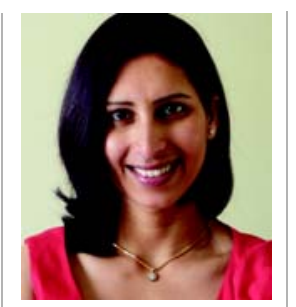

Ranjana Srivastava MB BS(Hons), FRACP, Medical Oncologist

Department of Medical Oncology, Southern Health, Melbourne, VIC.

Ranjana.srivastava@ southernhealth.org.au

doi: $10.5694 / \mathrm{mjal} 2.10718$

\section{When we} bemoan the disparity between populations, we need to account for our own hand in creating it facilities lack essential drugs. While those holidaying in the Bahamas ponder the issue of dying well, their counterparts in Bangladesh look on in bemusement, as they try to outsmart death at every move. After all, beating death is hard work when a billion people globally defecate openly, and more than twice that number endure substandard sanitation facilities. It must be difficult to understand people opting out of immunisation when your child becomes one of the 2 million dying because you can't access vaccination. Prophylaxis is a cruel pipedream when treatment is beyond reach. It must be quaint to think about stem cell therapy when your drinking water is crawling with parasites.

$$
* * *
$$

I am fortunate. Having lived and worked in impoverished surroundings that force mankind to plumb the depths of despair, I have the choice of returning home to the West. I work in a system that despite crying poor seems anything but. I assume this is why we can casually discard halfempty vials of the most precious drugs. I assume this is why we can perform multiple ECGs when one would suffice. And why we routinely mistake ordering a dozen exotic tests to replace one good history.

Looking back and looking forward, I see that much of the narrative around rich-world-poor-world medicine seems to be just that - narrative. Doctors travel far to serve the most wretched of humanity. While there, we give it our all. We bring back stories of penury, inequality and suffering that compete with each other for the wide-eyed disbelief they induce. Surely, a course of penicillin was all it would've taken to cure the woman's sexually transmitted infection. How could any midwife safely deliver 20 babies each night? Why could nobody resuscitate the child?

Then we return to our "normal" work and cordon off that experience. As if that "other" experience were so extraordinary that placing it in the context of modern-day work is unthinkable. If you can summon six doctors to assess a patient on a hunch, what good is it to recall the patient who died of untreated cellulitis? If you can empirically add the most expensive antibiotic available on the market, why recall the desperation of having only expired doxycycline? If you and your immediate patients have access to clean water and good medicines, why should you take on the world's worries?

But I'd argue that for those who work in conditions of abundance, what should inform our practice are the memories of crying need, unmet. By failing to internalise the lessons of working in needy areas, and continuing to work in a bubble, we fail our unseen fellow man.

The challenge for the modern global-minded doctor then is not merely to debate efficient aid, rehabilitate unscrupulous officials, and mediate between warring 
health care factions. The real challenge is to let the direct and indirect experiences of inadequate health care inform every one of us on a daily basis as we practise wherever we are. From Sydney to Somalia, from Brussels to Burma, if doctors paused to think about the effect of their practice on the world, we will eventually effect real change.

On the ward round, I want my residents to think twice about the global implications of prescribing the newest antibiotic, sending a demented octogenarian to intensive care, or ordering an MRI scan when a conversation with a dying man's family would suffice. I want my peers to think whether lobbying for approval of another fashionable drug is the best use of our advocacy and intellect. When we berate pharmaceutical companies for their failure to invest in drugs for diseases that wipe out millions of people, we need to ask whether this has anything to do with our own prescribing habits. When we bemoan the disparity between populations, we need to account for our own hand in creating it. For as long as we define our work narrowly, global health will be a conversation about them and us. But the very real troubles that plague global health are our troubles too. It's not enough to feel sorry for the malnourished, sick family that fronts an ad campaign but for a turn of circumstances, that could be us. An interest in global health will mean something the day we believe this and change the way we practise.

\section{Stamps of greatness}

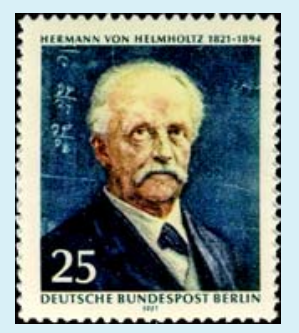

Hermann Ludwig Ferdinand von Helmholtz (1821-1894)

Helmholtz was born on 31 August 1821, in Potsdam, Germany. He began his medical life as a surgeon in the Prussian Army. At the University of Berlin he came under the influence of Johannes Muller and Gustav Magnus. His inaugural dissertation in 1842 dealt with the origin of nerve fibres from cells in the ganglia of leeches and crabs, which he had observed with a rudimentary compound microscope.

Helmholtz published his famous essay on the conservation of force in 1847, which established his reputation; indeed, he is regarded as one of the founders of the law of conservation of energy.

His first academic position was associate professor of physiology at the Prussian University of Königsberg, in 1849. In 1855 he was appointed professor of anatomy and physiology at the University of Bonn, also in Prussia. He was not particularly happy in Bonn, however, and three years later he transferred to the University of Heidelberg, in Baden, where he served as professor of physiology. In 1871 he accepted his final university position, as professor of physics at the University of Berlin.

Helmholtz is best known for his work in optics and as the inventor of the ophthalmoscope. This instrument made it possible for physicians to examine the inside of the living human eye for the first time, to study the physiology and pathology of the eye and diagnose refractive errors. This invention was followed by that of the phakoscope and ophthalmometer.

Helmholtz wrote a treatise on physiological optics, which supported Young's theory of colour vision, and explained the curvature of the lens.

He also published a masterly study of acoustics in 1963 and studied the mechanism of the tympanum and ossicles of the middle ear in 1869, which did much to elucidate the mechanism of hearing.

In 1850-1852, Helmholtz measured the velocity of the nervous impulse with a pendulum-myograph of his invention. He also added to Skoda's work on percussion and auscultation (1839) to analyse the sounds of the chest for teaching purposes, and pioneered the use of quinine sulphate on the nasal mucous membrane for hay fever (1869).

Only Huxley, Tindall and Mach come close to Helmholtz in his efforts to popularise science through his writings and lectures. He was postally honoured as a great scientist by Germany in 1950, and again in 1971.

AMA Gazette 1982; Jan.

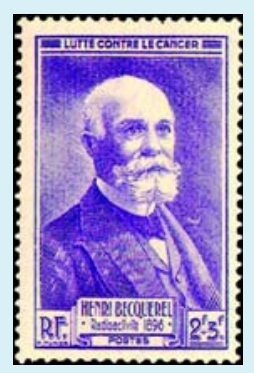
Antoine Henri Becquerel (1852-1908)

BECQUEREL was born in Paris on 15 December 1852. He studied physics and became a professor at the Museum of Natural History in 1892 and at the Polytechnic Institute of Paris in 1895 .

In 1896 he discovered the so-called Becquerel rays of radioactivity, which emanated from uranium, and thus unknowingly laid the foundation for atomic fission.

After doing important work on the polarisation of light he noted that salts of uranium emit rays capable of passing through various screens. These rays were later identified with the alpha, beta and gamma rays of Roentgen's x-rays.

The discovery of the radioactivity of uranium by Becquerel led Pierre Curie (1859-1906) and Marie Curie (1867-1934) to isolate from literally tons of pitchblende minute quantities of a particularly strong radioactive substance in 1898. Madame Curie was able, by painstaking study, to identify this substance as a new element, radium.

For this work, Becquerel received, together with Pierre and Marie Curie, the Nobel Prize in Physics in 1903.

His work later became the basis for the radioactive treatment of cancer.

Becquerel died on 25 August 1908, in Croisie, Brittany, and was postally honoured by France in 1946 on a stamp, the proceeds of which were devoted to the fight against cancer.

AMA Gazette 1977; Jun. 